\title{
Photoadaptation to intermittent light across the St. Lawrence Estuary freshwater-saltwater transition zone*
}

\author{
Warwick F. Vincent, Normand Bertrand, Jean-Jacques Frenette \\ Département de Biologie, Université Laval, Sainte-Foy, Québec, Canada G1K 7P4
}

\begin{abstract}
We evaluated 2 competing hypotheses for the photoadaptive characteristics of phytoplankton distributed across the turbid freshwater-saltwater transition zone (TZ) of the St. Lawrence River (Canada): that the communities were photosynthetically adapted to a low mean water column irradiance, or that they were adapted to intermittent exposure to near-surface irradiance conditions. Two cruises were undertaken in spring-early summer, a period that corresponded to major seasonal changes in the optical environment of the St. Lawrence River. There was a large increase in chlorophyll a (chl a) concentration, maximum photosynthetic rates $\left(P_{\max }^{\mathrm{B}}\right)$, and the light saturation parameter $\left(I_{k}\right)$ between the 2 cruises. During this period the nanoplankton (cells in the size range 2 to $20 \mu \mathrm{m}$ ) rose from 33 to $69 \%$ of total chl a. There were no major shifts in photosynthetic characteristics across the transition from freshwater to turbid saltwater conditions, but rather the cells maintained high values of $p^{B}$ max and $I_{k}$, with low $\alpha$ (the light limitation parameter) and little inhibitory response to high photon fluence rates. These observations support the hypothesis that the phytoplankton community in this and perhaps other turbid environments are photoadapted to 'intermittent sun' conditions, rather than the 'shade environment' experienced on average through the water column.
\end{abstract}

KEY WORDS: Estuary · Mixing · Photoadaptation - Photosynthesis - Phytoplankton - River - Turbidity

\section{INTRODUCTION}

In turbid estuaries the limiting factor for algal production is often considered to be light rather than nutrient supply (Joint \& Pomroy 1981, Uncles \& Joint 1983, Cole \& Cloern 1984, Cloern et al. 1985, Pennock 1985, Pennock \& Sharp 1986). Underwater light availability is controlled by the variations in incident solar radiation, the diffuse attenuation characteristics of the water column, and the mixing and stratification regime. These variables are in turn influenced by the unique combination of physical properties of the estuarine environment: tidal mixing, estuarine recirculation, major gradients in salinity and suspended sediment, and complex changes in bathymetry. For this reason the structure and dynamics of estuaries are

\footnotetext{
- Contribution to the programme of CEN (Centre d'études nordiques) and GIROQ (Groupe Interuniversitaire de Recherches Océanographiques du Québec)
}

likely to differ from those of other marine and freshwater ecosystems (Cole \& Cloern 1984), and their phytoplankton communities are likely to have photosynthetic properties that reflect this distinct environmental regime.

The freshwater-saltwater transition zone (TZ) of the St. Lawrence River, Canada, begins approximately $30 \mathrm{~km}$ downstream of Québec City, and is the upstream, frontal region of the maximum turbidity zone of the St. Lawrence estuary. Although several authors have speculated on the severe light limitation that might be imposed on phytoplankton in this turbid zone (Cardinal \& Bérard-Therriault 1976, Therriault et al. 1990), there has been no consideration of the mixing and stratification regime, nor any previous attempt to measure photosynthesis in the TZ.

The aim of this present study was to measure the changes in primary production characteristics across the turbidity gradient associated with the St. Lawrence 
River TZ. Two photoadaptive strategies could potentially operate within this region: shade adaptation to the low mean water column irradiances, or alternatively, sun adaptation to the bright near-surface light conditions experienced during intermittent mixing to the surface of the water column. We evaluated these potential responses as 2 competing hypotheses (photoadaptation to mean shade, or photoadaptation to intermittent sun conditions) by means of 2 cruises across the $\mathrm{TZ}$ in late spring-early summer. This period coincides with the development of large populations of fish larvae in the TZ (Microgadus tomcod and Osmerus mordax; see Dodson et al. 1989, Laprise \& Dodson 1989), and it is also a time of major changes in the turbidity of the freshwater section of the river. This sampling program therefore encompassed a wide range of optical conditions in which to examine the photosynthesis-light responses.

\section{METHODS}

Two sampling cruises were undertaken, the first from 10 to 14 May 1991 and the second from 27 June to 1 July 1991. During the first cruise 12 stations were sampled in the upper St. Lawrence Estuary (Fig. 1):

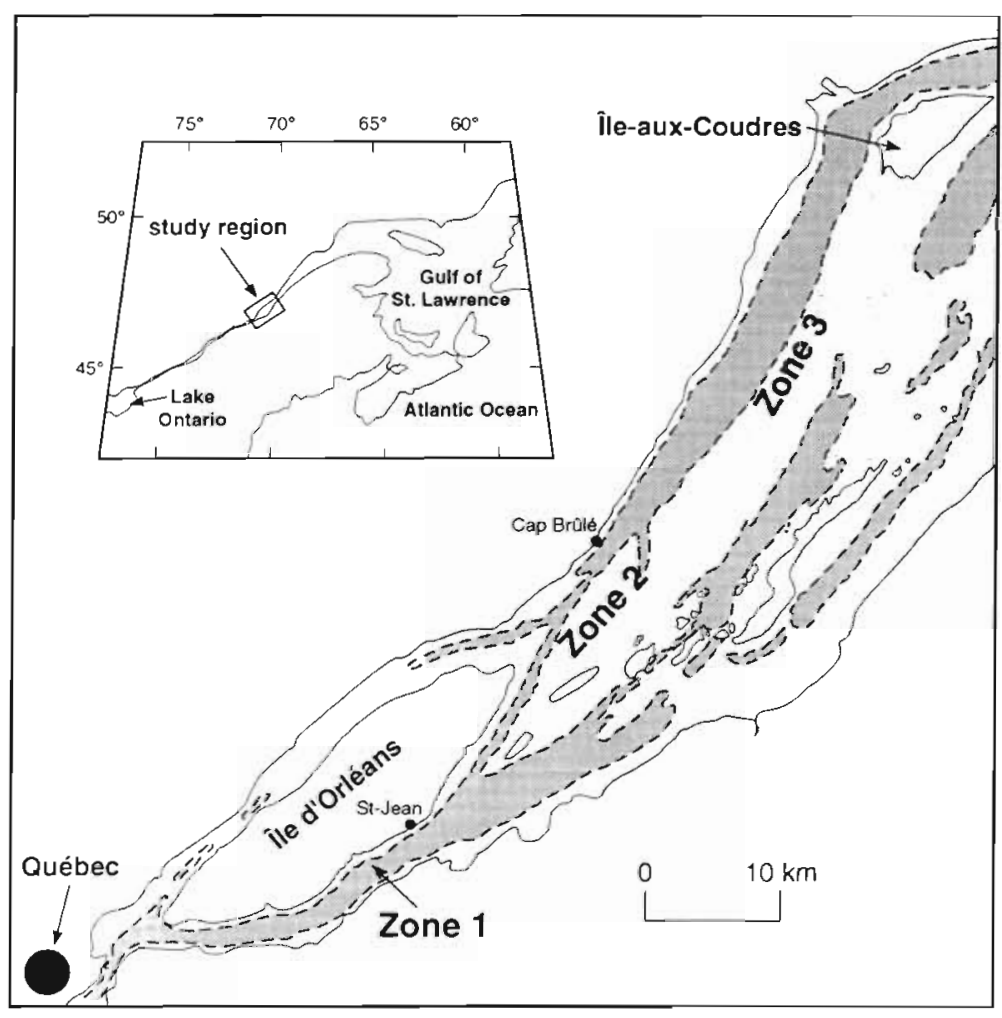

Fig. 1. Position of sampling sites across the St. Lawrence River transition zone. Dark shading: regions with a maximum depth $>10 \mathrm{~m}$
4 stations in the lower freshwater (but tidal) section ca $30 \mathrm{~km}$ downstream of Québec City (Zone 1); 4 stations in the frontal region of increased turbidity with surface salinities in the range 0.7 to $2 \%$ (Zone 2 ); and 4 stations $30 \mathrm{~km}$ further downstream with surface water salinities in the range 4 to $8 \%$ (Zone 3 ). Each zone was sampled over $24 \mathrm{~h}$, twice at low tide and twice at high tide.

Zone 1 and the Zone 2 frontal region were more intensively studied in the second cruise to obtain better temporal resolution. A fixed station was occupied in each zone and sampled at high and low tides over 3 tidal cycles. The freshwater station was located ca $500 \mathrm{~m}$ off St. Jean (Île d'Orléans) and the TZ station was located within $1 \mathrm{~km}$ of Cap Brulé (north shore).

At each sampling time during the 2 cruises water was sampled from near the surface $(0.5 \mathrm{~m})$ and near the bottom $(17 \mathrm{~m}$, which was at least $3 \mathrm{~m}$ above the sediments) with a 51 GO-FLOW bottle. Temperature and salinities were obtained with a Sea Bird CTD probe model Sealogger SBE-19. Quantum scalar irradiance was measured with a Biospherical Instrument Co. $4 \pi$ irradiance sensor (model QSP-160) connected to a QSP-170B integrating meter. Turbidity was assessed by dry weight analysis of the seston filtered onto preweighed GF/F glass fiber filters.

Samples for nutrient analysis were prefiltered through GF/F filters, stored frozen and later analysed on a Alpkem model RFA-300 autoanalyser. Nitrate was measured by diazotization after cadmium reduction to nitrite (American Public Health Association 1976), dissolved reactive phosphorus (DRP) by the method of Whitledge et al. (1981), and silicate after repolymerization at room temperature, by the method of Truesdale \& Smith (1975), The limits of detection were $0.2 \mu \mathrm{mol} P$ or Si $l^{-1}$, and $0.05 \mu \mathrm{mol} \mathrm{N} \mathrm{l}^{-1}$.

Subsamples of water for chlorophyll a (chl a) fractionation were prefiltered through either a Nitex $200 \mu \mathrm{m}$ screen (total fraction), a Nitex $20 \mu \mathrm{m}$ screen (<20 $\mu \mathrm{m}$ fraction) or a Nuclepore $2 \mu \mathrm{m}$ filter (picoplankton, $<2 \mu \mathrm{m}$ fraction), and then were filtered onto $25 \mathrm{~mm}$ Whatman $\mathrm{GF} / \mathrm{F}$ filters. Care was taken to rinse each prefilter with GF/F-filtered sample water during and at the end of filtration to minimize filter blockage effects. The GF/F filters were stored frozen and subsequently ground in $90 \%$ acetone with a Teflon tissue grinder. The extract was cleared by centrifugation and assayed by spectrofluorometry (Shimadzu spectrofluorometer 
Model RF5000U) before and after acidification (Strickland \& Parsons 1972)

Primary production was evaluated by the ${ }^{14} \mathrm{C}$ method (Strickland \& Parsons 1972). Each sample was immediately dispensed into ten $70 \mathrm{ml}$ Corning bottles and inoculated with $4.2 \mu \mathrm{Ci}$ of $\mathrm{NaH}^{14} \mathrm{CO}_{3}$. DCMU [3(3,4-dichlorophenyl)-1,1-dimethylurea] was added to a control bottle for each depth (final concentration $=10^{-5}$ $M)$. The bottles were then placed in a linear type incubator set to in situ temperatures with a water bath. The incubations were for $2 \mathrm{~h}$ under a gradient of light intensities from 50 to $1200 \mu \mathrm{mol}$ photons $\mathrm{m}^{-2} \mathrm{~s}^{-1}$ provided with a $250 \mathrm{~W}$ Optimarc high pressure sodium lamp. At the end of the incubation subsamples were filtered (with or without fractionation) onto $25 \mathrm{~mm}$ GF/F filters which were then stored frozen. These were later acidified in an $\mathrm{HCl}$ atmosphere for $5 \mathrm{~min}$ and placed in $20 \mathrm{ml}$ scintillation vials with $10 \mathrm{ml}$ Cytoscint scintillation liquid, and then counted with a LKB 1219 Rack Beta scintillation counter. Dissolved inorganic carbon was measured by shipboard $\mathrm{pH}$ determinations and potentiometric titration of samples from each station and depth.

Carbon fixation rates were normalized to chl a $\left(P^{\mathrm{B}}\right)$ and plotted as a function of light intensity. The exponential equation of Platt et al. (1980) was used to calculate the photosynthetic parameters:

$$
P^{\mathrm{B}}=P_{s}^{\mathrm{B}}\left[1-\exp \left(-\alpha I / P^{\mathrm{B}}{ }_{s}\right)\right] \exp \left(-\beta I / P^{\mathrm{B}}\right)
$$

In this equation, $P_{s}^{B}\left(\mu g C \mu g^{-1} c h l a h^{-1}\right)$ is defined as the maximum, potential, light-saturated photosynthetic rate (i.e. in the absence of photoinhibition); $\alpha$ is the initial slope $\left[\mu \mathrm{g} \mathrm{C} \mu \mathrm{g}^{-1} \mathrm{chl} a \mathrm{~h}^{-1} \text { ( } \mu \mathrm{mol} \mathrm{m} \mathrm{m}^{-2} \mathrm{~s}^{-1}\right)^{-1}$ ] which characterizes the photoreaction kinetics at low irradiances; $I$ is irradiance ( $\mu$ mol photons $\mathrm{m}^{-2} \mathrm{~s}^{-1}$ ); and $\beta$ is the photoinhibition parameter and characterizes photosynthesis under bright light. For most of our curves there was little or no evidence of photoinhibition, and we therefore set $\beta=0$, and thus $P_{\text {max }}^{\mathrm{B}}=P^{\mathrm{B}}$. For $\beta>0$ (i.e. some photoinhibition) we calculated $P_{\text {max }}^{\mathrm{B}}$ from $P^{\mathrm{B}}$ as in Platt et al. (1980). All of the curve fits were by non-linear regression using the Gauss-Newton method. The light adaptation index $I_{k}$ (Talling 1957) was calculated as $P_{\max }^{\mathrm{B}} / \alpha$.

Mean depth was calculated by digitized estimates of the areas delimited by specific isobaths within 5 nautical mile $(9 \mathrm{~km})$ sections of the river, using the 1:50000 bathymetric charts provided by the Canadian Hydrographic Service. Mean water column irradiance $\left(I_{a v}\right)$, expressed as a percentage of surface irradiance, was calculated as in Vincent (1983):

$$
I_{\mathrm{av}}=\left[100 \% /\left(-Z_{\mathrm{m}} k\right)\right]\left[\exp \left(-k Z_{\mathrm{m}}\right)-1\right]
$$

where $Z_{\mathrm{m}}$ is mixing depth and $k$ is the measured diffuse attenuation coefficient for underwater PAR.

\section{RESULTS}

\section{Physical and chemical environment}

During the mid-May cruise the mean water temperatures were in the range 7 to $10^{\circ} \mathrm{C}$, and salinities increased from freshwater values $(0.1 \%$ ) in Zone 1 to $10 \%$ in the bottom waters of Zone 3 (Fig. 2). The water column was always isothermal in Zone 1 , but the CTD profiles showed weak discontinuous stratification in Zone 2, and stronger, persistent stratification in Zone 3. For the data in Fig. 2 the mixing depth $\left(Z_{\mathrm{m}}\right)$ was approximated as the mean water column depth in Zones 1 and 2, but the depth of the main pycnocline in Zone 3.

Temperatures were about $10^{\circ} \mathrm{C}$ higher in the second cruise (June-July), ranging from $21^{\circ} \mathrm{C}$ in freshwater Zone 1 to $16^{\circ} \mathrm{C}$ at high tide in Zone 2 . The salinity bracketed a similar range to that measured in the first cruise. There was no evidence of density stratification in Zone 1, but in Zone 2 the extent of stratification varied over the tidal cycle (Fig. 2). The mixing depth $\left(Z_{\mathrm{m}}\right)$ was approximated as the mean water column depth in Zone 2 at low tide, but as the depth of the pycnocline (around $2 \mathrm{~m}$ ) in Zone 2 at high tide.

In the first cruise the depth of the $1 \%$ PAR level was 3-fold deeper in Zone 1 than Zone 2, while Zone 3 was only slightly less turbid than Zone 2 and thus had a similar euphotic depth $\left(Z_{\text {eu }}\right)$ (Table 1). Zone 2 contained the maximum seston concentrations, and corresponded to the maximum turbidity zone as described by Kranck (1979) and Lucotte \& d'Anglejan (1986).

Table 1. Physical properties of the 3 sampling zones across the St. Lawrence River transition. Values presented are averages $( \pm S E)$ for the diffuse attenuation coefficient $\left(K, \mathrm{~m}^{-2}\right)$, euphotic depth $\left(Z_{\text {eu }}\right)$, water mixing depth $\left(Z_{\mathrm{m}}\right)$, $Z_{\text {eu }} / Z_{\mathrm{m}}$ ratio for the zones, and mean irradiance for the water column as a percentage of surface incident irradiance (\% light). HT: high tide; LT: low

\begin{tabular}{|c|c|c|c|c|c|c|}
\hline Zone & $\mathrm{n}$ & $K$ & $Z_{\text {eu }}$ & $Z_{\mathrm{rn}}$ & $Z_{\mathrm{eu}} / Z_{\mathrm{m}}$ & $\%$ light \\
\hline \multicolumn{7}{|c|}{ Cruise 1 (mid-May) } \\
\hline 1 & 2 & $1.6(0.9)$ & $2.9(0.2)$ & 24.0 & 0.12 & 2.6 \\
\hline 2 & 2 & $5.1(0.8)$ & $0.9(0.2)$ & 6.3 & 0.14 & 3.1 \\
\hline 3 & 2 & $3.8(0.5)$ & $1.2(0.2)$ & 8.3 & 0.14 & 3.2 \\
\hline \multicolumn{7}{|c|}{ Cruise 2 (late June) } \\
\hline 1 & 5 & $1.1(0.1)$ & $4.2(0.1)$ & 24.0 & 0.18 & 3.8 \\
\hline $2(\mathrm{LT})$ & 2 & $4.8(0.1)$ & $1.0(0.0)$ & 6.0 & 0.17 & 3.5 \\
\hline $2(\mathrm{HT})$ & 1 & $2.0(-)$ & $2.3(-)$ & 6.6 & 0.35 & 7.6 \\
\hline
\end{tabular}
tide; $n$ : number of sampling profiles 


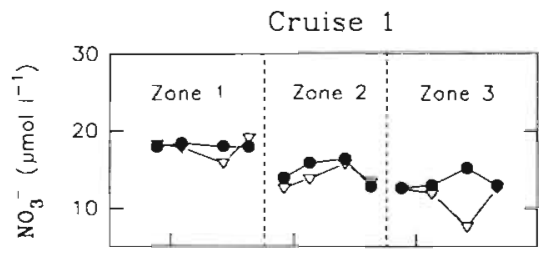

Cruise 2
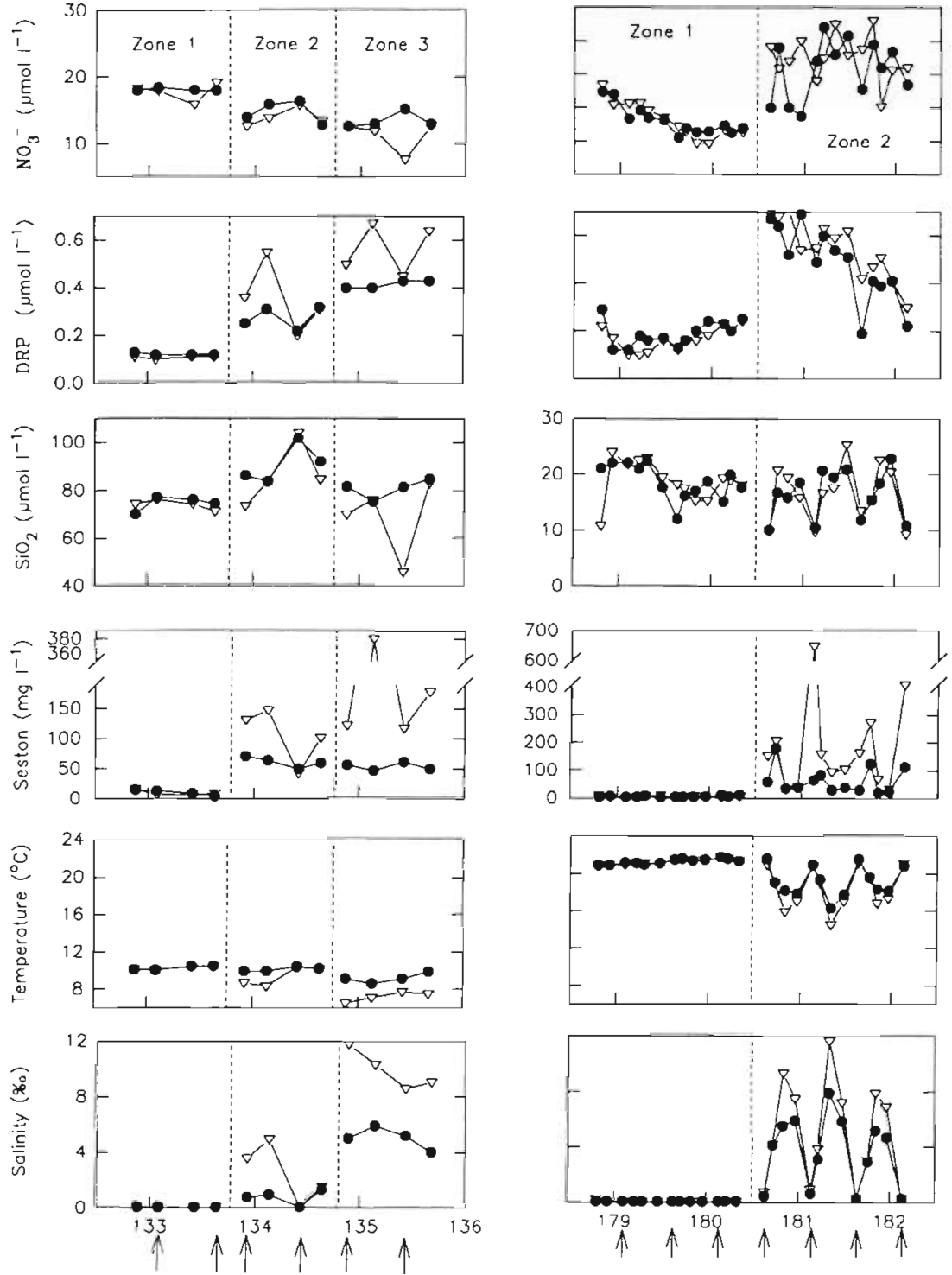

Julian day
There was a large increase in water column transparency between the 2 cruises, especially in the freshwater zone in which the depth of the $1 \%$ light level increased by a factor of 2 . In Zone 2 the transparency varied according to tidal state, with greatest light penetration at high tide.

Mean depth decreased 4 -fold between Zones 1 and 2 , and therefore despite the large increase in turbidity the ratio $Z_{\mathrm{eu}} / Z_{\mathrm{m}}$ was approximately the same for the 2 zones (Table 1). Mean depth increased by $32 \%$ in Zone 3 and to a much greater extent further downstream. There was little change in the underwater light availability between Zones 1 and 2 as can be seen by a comparison of average water column irradiances, which were 3 to $4 \%$ in both zones.
There were no major differences in nitrate or DRP concentration between mid-May and the end of June, but silicate levels dropped substantially between cruises (Fig. 2). In both cruises there was a significant rise in DRP from Zones 1 to 2 , and in the second cruise there was a significant rise in $\mathrm{NO}_{3}^{-}$concentrations across this transition. There were no significant differences between zones in the dissolved inorganic carbon values within each cruise, but there was a significant rise between cruises, from a mean of 16.6 (SD $=1.7) \mathrm{g} \mathrm{m}^{-3}$ in Cruise 1 to $21.2(\mathrm{SD}=1.2) \mathrm{g} \mathrm{m}^{-3}$ in Cruise 2 ( $t$ for the difference between cruises $=5.25$, $p<0.001$ ).

These changes in the physical and chemical properties of the St. Lawrence River system were accompa- 


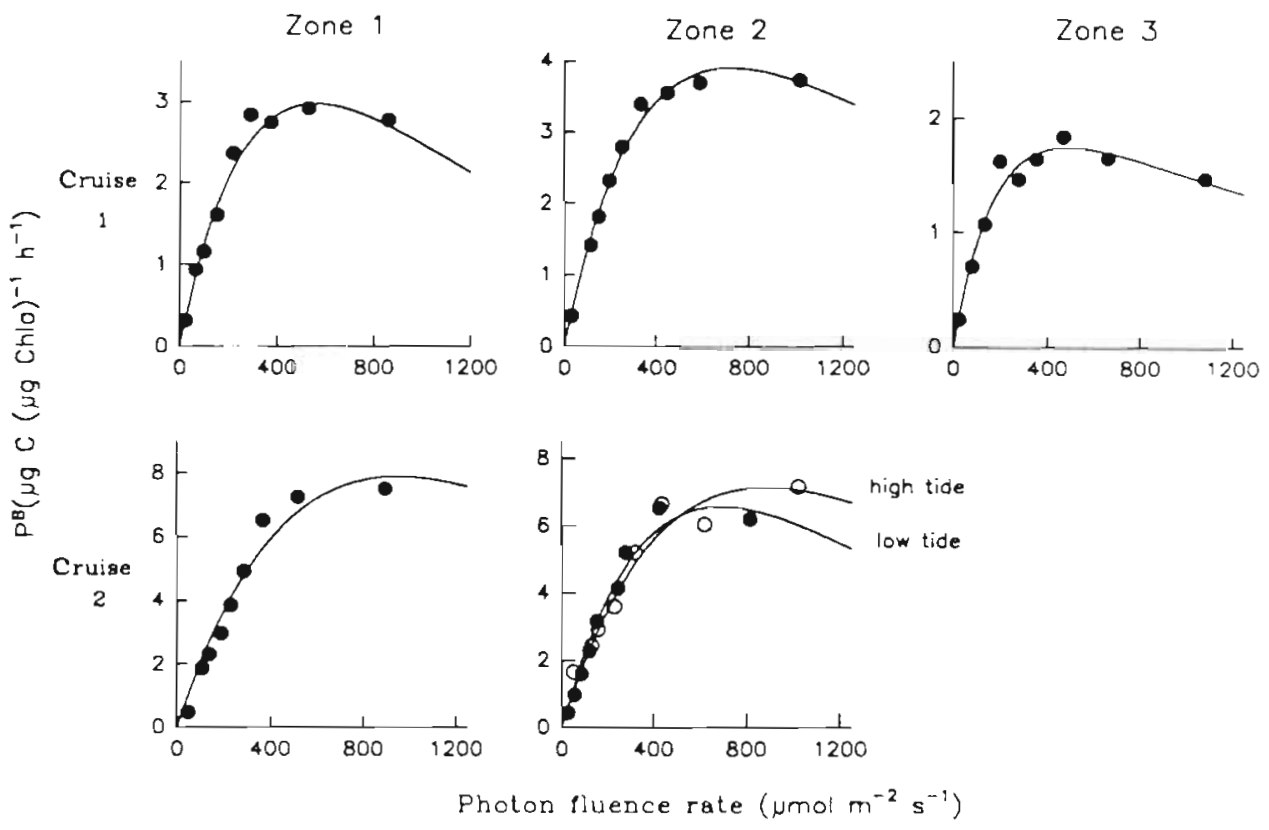

Fig. 3. Representative photosynthesis-light curves for the 2 cruises. For the Zone 2, Cruise 2 curves, (O) high tide; (O) low tide

nied by a major decrease in freshwater discharge. The $6 \mathrm{wk}$ interval between the 2 cruises corresponded to the transitional period between the end of the spring flood associated with snow melt, and the onset of more stable flow conditions in summer. The mean discharge of the river at Québec City was $16400 \mathrm{~m}^{3} \mathrm{~s}^{-1}$ during the mid-May cruise, falling to 10400 $\mathrm{m}^{3} \mathrm{~s}^{-1}$ in the second cruise (Environment Québec unpubl. data).

\section{Photosynthetic parameters}

The measured $P$ versus $I$ parameters $\left(\alpha, P_{\max }^{\mathrm{B}}, I_{k}\right.$ and $\%$ photoinhibition) changed little between Zones 1 and 2 during either of the 2 cruises, but there were large changes in these parameters between Zones 2 and 3, and between cruises (Fig. 3). During the first cruise the mean $P^{\mathrm{B}}$ max values did not vary significantly $(p>0.05)$ between Zones 1 and 2, nor with depth of sampling $(0.5$ and $17 \mathrm{~m})$ (Fig. 4). However in Zone 3 there was a significant drop $(\mathrm{p}=0.005)$ in $P_{\text {max }}^{\mathrm{B}}$ at $0.5 \mathrm{~m}$, and to a much greater extent at $17 \mathrm{~m}$.
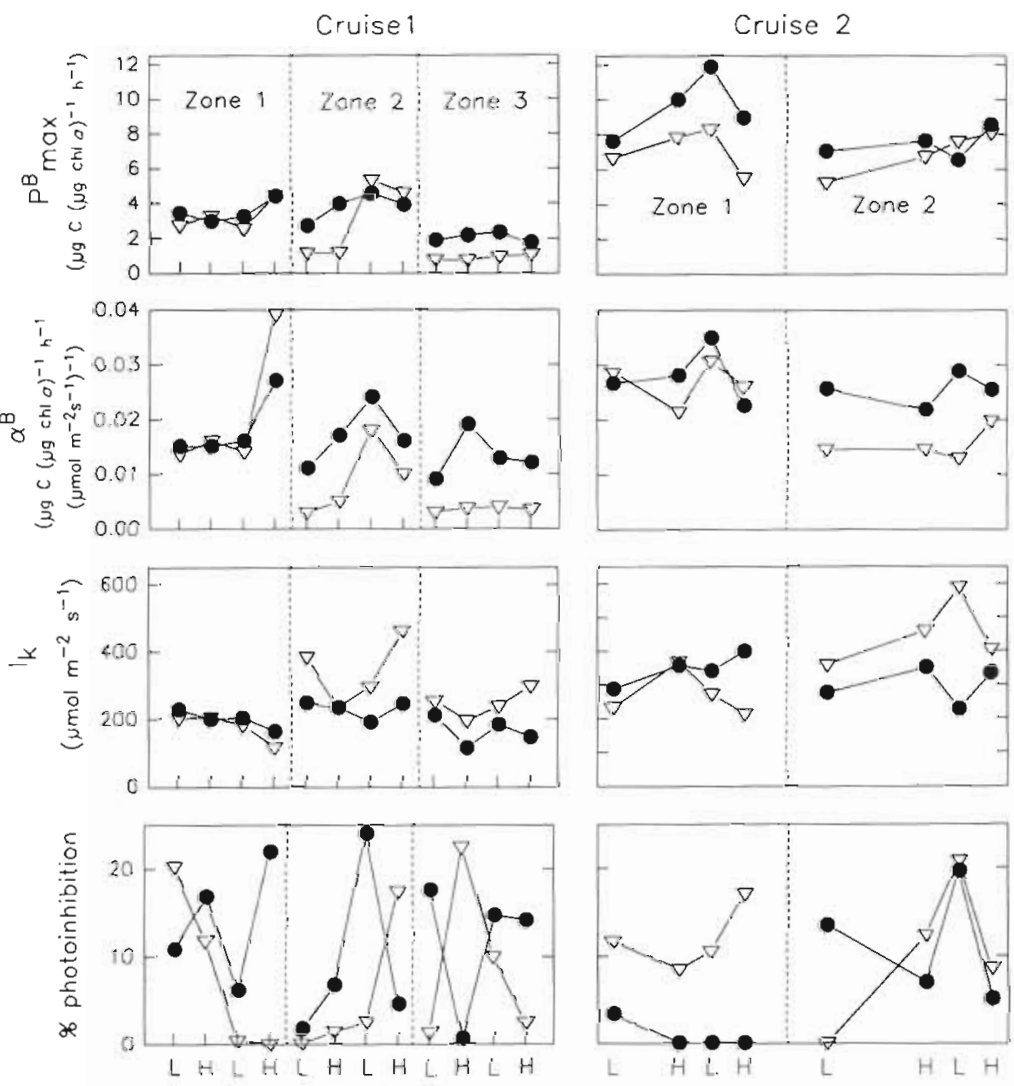

Fig. 4. Photosynthetic parameters during the 2 cruises. Each point represents a single estimate derived from a photosynthesis-light curve regression analysis. L: low tide; H: high tide; $(0.5 \mathrm{~m} ;(\nabla) 17 \mathrm{~m}$ 
Table 2. Distribution of total and fractionated chl a (picoplankton: $<2 \mu \mathrm{m}$; nanoplankton: 2 to $20 \mu \mathrm{m}$; microplankton: 20 to $200 \mu \mathrm{m}$ ) for both cruises. Each value is the mean for 4 samples ( \pm SE). The \% contribution to total chl a is given under the chl a concentration values for each fraction. HT: high tide; LT: low tide; IT: intermediate tide

\begin{tabular}{|c|c|c|c|c|c|c|}
\hline \multirow[t]{2}{*}{ Zone } & \multirow{2}{*}{$\begin{array}{l}\text { Depth } \\
\text { (m) }\end{array}$} & \multirow[t]{2}{*}{$\mathrm{n}$} & \multirow[t]{2}{*}{ Total chl a } & \multicolumn{3}{|c|}{ Fractionated chl a $\left(\mu \mathrm{g} \mathrm{l}^{-1}\right)$} \\
\hline & & & & Picoplankton & Nanoplankton & Microplankton \\
\hline \multicolumn{7}{|c|}{ Cruise 1} \\
\hline \multirow[t]{2}{*}{1} & 0.5 & 4 & $6.6(0.4)$ & $1.8(0.3)$ & $\begin{array}{c}2.2(0.2) \\
32 \%\end{array}$ & $2.6(0.3)$ \\
\hline & 17.0 & 4 & $6.8(0.4)$ & $\begin{array}{c}2.1(0.4) \\
32 \%\end{array}$ & $\begin{array}{c}2.0(0.3) \\
29 \%\end{array}$ & $\begin{array}{c}2.7(0.2) \\
39 \%\end{array}$ \\
\hline \multirow[t]{2}{*}{2} & 0.5 & 4 & $5.0(0.6)$ & $\begin{array}{c}0.8(0.3) \\
16 \%\end{array}$ & $\begin{array}{c}1.3(0.3) \\
26 \%\end{array}$ & $\begin{array}{c}2.9(0.4) \\
58 \%\end{array}$ \\
\hline & 17.0 & 4 & $5.0(0.3)$ & $\begin{array}{c}0.5(0.2) \\
10 \%\end{array}$ & $\begin{array}{c}1.5(0.3) \\
30 \%\end{array}$ & $\begin{array}{c}3.0(0.1) \\
60 \%\end{array}$ \\
\hline \multirow[t]{2}{*}{3} & 0.5 & 4 & $1.2(0.3)$ & $\begin{array}{c}0.3(0.1) \\
25 \%\end{array}$ & $\begin{array}{c}0.5(0.1) \\
33 \%\end{array}$ & $\begin{array}{c}0.4(0.1) \\
42 \%\end{array}$ \\
\hline & 17.0 & 4 & $3.5(1.2)$ & $\begin{array}{c}0.3(0.1) \\
9 \%\end{array}$ & $\begin{array}{c}1.3(0.4) \\
37 \%\end{array}$ & $\begin{array}{c}1.9(0.6) \\
54 \%\end{array}$ \\
\hline \multicolumn{7}{|c|}{ Cruise 2} \\
\hline \multirow[t]{2}{*}{1} & 0.5 & 13 & $11.9(0.4)$ & $\begin{array}{c}1.7(0.1) \\
14 \%\end{array}$ & $\begin{array}{c}8.7(0.4) \\
73 \%\end{array}$ & $\begin{array}{c}1.5(0.2) \\
13 \%\end{array}$ \\
\hline & 17.0 & 13 & $12.4(0.3)$ & $\begin{array}{c}1.9(0.1) \\
15 \%\end{array}$ & $\begin{array}{c}8.3(0.3) \\
67 \%\end{array}$ & $\begin{array}{c}2.2(0.3) \\
18 \%\end{array}$ \\
\hline \multirow[t]{2}{*}{2} & $0.5(\mathrm{LT})$ & 4 & $10.1(1.4)$ & $\begin{array}{c}0.9(0.3) \\
9 \%\end{array}$ & $\begin{array}{c}7.9(1.2) \\
78 \%\end{array}$ & $\begin{array}{c}1.3(0.2) \\
13 \%\end{array}$ \\
\hline & 17.0 & 4 & $16.6(1.0)$ & $\begin{array}{c}1.0(0.1) \\
6 \%\end{array}$ & $\begin{array}{c}10.6(0.6) \\
64 \%\end{array}$ & $\begin{array}{c}5.0(0.4) \\
30 \%\end{array}$ \\
\hline \multirow[t]{2}{*}{2} & $0.5(\mathrm{HT})$ & 3 & $1.9(0.4)$ & $\begin{array}{c}0.5(0.1) \\
25 \%\end{array}$ & $\begin{array}{c}1.3(0.4) \\
65 \%\end{array}$ & $\begin{array}{c}0.2(0.1) \\
20 \%\end{array}$ \\
\hline & 17.0 & 3 & $1.9(0.2)$ & $\begin{array}{c}0.3(0.0) \\
16 \%\end{array}$ & $\begin{array}{c}1.2(0.2) \\
63 \%\end{array}$ & $\begin{array}{c}0.4(0.1) \\
21 \%\end{array}$ \\
\hline \multirow[t]{2}{*}{2} & $0.5(\mathrm{IT})$ & 6 & $3.3(0.6)$ & $\begin{array}{c}0.6(0.2) \\
18 \%\end{array}$ & $\begin{array}{c}2.2(0.4) \\
67 \%\end{array}$ & $\begin{array}{c}0.5(0.1) \\
15 \%\end{array}$ \\
\hline & 17.0 & 6 & $4.0(0.7)$ & $\begin{array}{c}1.0(0.3) \\
25 \%\end{array}$ & $\begin{array}{c}2.8(0.4) \\
70 \%\end{array}$ & $\begin{array}{c}0.2(0.1) \\
5 \%\end{array}$ \\
\hline
\end{tabular}

The greatest changes in $P_{\text {max }}^{\mathrm{B}}$ occurred between cruises. The average values increased approximately 2 -fold in the second cruise, and unlike in May, $P_{\max }^{\mathrm{B}}$ was always significantly higher at $0.5 \mathrm{~m}$ than at $17 \mathrm{~m}$ in Zone 1 . The mean $P_{\text {max }}^{\mathrm{B}}$ at the surface dropped slightly (but $\mathrm{p}=0.07$ ) across the transition from Zones 1 to 2 , from 9.6 to $7.1 \mu \mathrm{g} \mathrm{C} \mathrm{\mu g}^{-1} \mathrm{chl} \mathrm{a} \mathrm{h}^{-1}$.

The light limitation parameter $\alpha$ for the surface waters did not change significantly between zones in either cruise. However in Zones 2 and 3 the $17 \mathrm{~m}$ sample had a lower value relative to the surface (Fig. 4). These effects on $\alpha$ combined with the relative constancy of $P_{\text {max }}^{B}$ translated into similar trends for $I_{k}$. This parameter varied non-significantly between zones, but increased with depth in Zones 2 and 3.

Photoinhibition, expressed as the percent reduction of $P_{\text {max }}^{\mathrm{B}}$ at $1000 \mu \mathrm{mol}$ photons $\mathrm{m}^{-2} \mathrm{~s}^{-1}$, varied between 0 and $24 \%$. During the second cruise in Zone 1 at $0.5 \mathrm{~m}$ there was no evidence of photoinhibition in the Zone 1 surface sample, but in all other waters the values ranged between 0 and $22 \%$ with no significant differences between samples ( $p>0.05$ ).

\section{Phytoplankton biomass}

During the first cruise there was no significant difference in chl a concentration between Zones 1 and 2, nor between the surface and bottom water samples (Table 2). The $3 \mathrm{chl}$ a fractions were equally represented in Zone 1, but the microplankton fraction (>20 $\mu \mathrm{m}$ ) dominated in Zone 2. Chl a concentration dropped abruptly in Zone 3 and the concentrations of microplankton and nanoplankton were higher at $17 \mathrm{~m}$ than at $0.5 \mathrm{~m}$.

In the second cruise, 6 wk later, chl a had increased 2 -fold in the freshwater Zone 1, and at low tide in Zone 2. Tidal state had no influence on chl a concentrations in the riverine freshwater section, but in Zone $2 \mathrm{chl}$ a dropped by a factor of 5 to 8 between low and high tides. At high tide in Zone 2 there was no significant difference between depths, but at low tide the $17 \mathrm{~m}$ sample had a $50 \%$ higher chl a concentration.

The changes in total chl a between cruises was largely the result of an increase in the nanoplankton. This fraction contributed on average $33 \%$ of the chl a 
during the first cruise, and increased to $69 \%$ in the second cruise. This shift was associated with a major decline in the importance of microplankton. The changes in picoplankton community biomass and structure within and between cruises are given in Bertrand \& Vincent (1994).

\section{DISCUSSION}

In the upstream freshwater region of the St. Lawrence Estuary as well as across the TZ, the euphotic depth was much less $(<20 \%)$ than the mixing depth, and cells were only intermittently exposed to irradiances that were sufficient for photosynthesis. Such conditions are characteristic of many estuarine ecosystems, e.g. the tidal freshwater section of the Hudson estuary (Cole et al. 1992), San Francisco Bay (Cloern 1987), and the Great Ouse, England (Fichez et al. 1992). Our results from the 2 cruises show that although the photosynthetic characteristics changed markedly over $6 \mathrm{wk}$, there was little spatial change between the upstream region and the transition zone. These observations imply a qualitatively similar phytoplankton response to the fluctuating light-dark regime in both environments,

\section{Temporal changes (Cruise 1 to Cruise 2)}

The St. Lawrence River system is subject to major changes in its physical environment at the end of the spring snowmelt period. In the $6 \mathrm{wk}$ between the 2 cruises, water temperatures increased by $11^{\circ} \mathrm{C}, Z_{\text {eu }}$ increased by $50 \%$, and daylength increased by $1 \mathrm{~h}$. These changes probably contributed to the 2 -fold increase in both $P_{\text {max }}^{\mathrm{B}}$ and chl a. The $P_{\text {max }}^{\mathrm{B}}$ values found in this study fall within the range reported in other estuaries (Harding et al. 1985, 1986, Pennock \& Sharp 1986, Madariaga \& Orive 1989). In the freshwater zone $I_{k}$ increased from 198 to $334 \mu \mathrm{mol}$ photons $\mathrm{m}^{-2} \mathrm{~s}^{-1}$ between cruises. This increase was probably a response to the increased light penetration into the water column, but it may have also reflected changes in the size structure of the phytoplankton community (cf. Côté \& Platt 1983).

Many studies on rivers and estuaries have identified the dominance of phytoplankton biomass by nanoplankton (e.g. Livery et al. 1983, Filardo \& Dunstan 1985, Cole et al. 1986, Ross \& Pieterse 1992). In the St. Lawrence River system, this size fraction rose to dominance in the second cruise at the expense of microplankton which dominated during the first cruise. Several factors may have influenced this seasonal change. The decrease in discharge in summer would have resulted in a decrease in friction velocity $\left(u^{\bullet}\right)$ and thus vertical mixing rate. This effect would have favoured a decrease in large cells which sediment rapidly. The 4 -fold decrease in silicate concentrations over this period would have slowed the growth of large diatoms, while small cell species, with their high surface-to-volume ratios, continued to grow rapidly

\section{Spatial changes in biomass}

Phytoplankton concentrations as measured by chl a changed across the $\mathrm{TZ}$, but to an extent that depended on season and tidal state. This temporal variability in the spatial pattern is consistent with previous observations in this region. Painchaud et al. (1990) found only a slight drop in surface chl a (2.9 to $2.6 \mu \mathrm{g} \mathrm{chl} \mathrm{a}^{-1}$ ) in mid-August 1987 across the transition from freshwater to slightly saline water (equivalent to our Zone 2). Cardinal \& Bérard-Therriault (1976) in summer 1971 and Painchaud \& Therriault (1989) in August 1982 observed much more severe changes in phytoplankton biomass across this transition. In our study we found no significant differences in chl a concentration between Zones 1 and 2 in the first cruise (Table 2), nor at low tide in the second cruise. However at other tidal states in the second cruise, chl a dropped by a factor of 5 to 8 The high concentrations of chl a at low tide may reflect the large amount of mechanical energy at the tidal front which acts to resuspend the sediments. This effect coupled with estuarine recirculation would cause an accumulation of cells in the frontal region. Consistent with this effect, the concentration of cells $>20 \mu \mathrm{m}$ (microplankton) was always significantly higher at $17 \mathrm{~m}$ than at $0.5 \mathrm{~m}$.

For the other tidal states, the drop in phytoplankton concentration is unlikely to have been the result of reduced growth (see below), but is more likely to have resulted from increased grazing losses. Dauvin \& Dodson (1990) demonstrated the importance of predation by fish larvae of the species Osmerus mordax on copepod and cladoceran zooplankton in this zone. Further down the food chain, strong pressure is in turn likely to be exerted on the phytoplankton. Both macrozooplankton and microzooplankton are also known to achieve high population densities within the TZ (Lovejoy et al. 1993).

\section{Spatial changes in photosynthesis}

The turbidity gradient across the transition was not accompanied by a significant shift in photosynthetic characteristics. $P^{B}{ }_{\max }$ was the most important photosynthetic parameter in this study because it indicated to what extent the cells passing from freshwater into 
the $\mathrm{TZ}$ were able to maintain their capacity to fix carbon. Previous authors had made the reasonable conjecture that this transition would be accompanied by a major drop in photosynthetic capacity, in part because of the shallowing of the euphotic zone (decreased $Z_{\text {eu }}$ ) associated with increased turbidity (Therriault et al. 1990). However, the availability of light within the water column depends not only on clarity, but also on the thickness of the mixed layer and thus the ratio $Z_{\mathrm{eu}} / Z_{\mathrm{m}}$ (Vincent 1983, Cloern 1987, Grobbelaar 1990). Our calculations show that the highly turbid Zone 2 had a $Z_{\text {eu }} / Z_{\mathrm{m}}$ ratio that was almost identical to Zone 1 , within the range 0.1 to 0.2 . Zone 2 could not, therefore, be considered deficient in light availability relative to Zone 1 .

Certain authors have attempted to identify critical values of $Z_{\mathrm{eu}} / Z_{\mathrm{m}}$, i.e. thresholds at which the net productivity equals zero, and the ratio of respiration/ photosynthesis equals 1 . Cloern (1987) estimated the critical $Z_{\mathrm{eu}} / Z_{\mathrm{m}}$ ratio to be 0.2 . However Grobbelaar (1990) found that, depending on the experimental conditions such as incident light intensity, temperature and chl a concentration, this ratio could be as low as 0.05 . The intensity of vertical mixing is likely to be a major factor influencing the photosynthetic characteristics of the phytoplankton, as well as the critical threshold value of $Z_{\mathrm{eu}} / Z_{\mathrm{m}}$ (e.g. Vincent 1983, 1990).

The vertical mixing of the water column in estuaries and other coastal environments is the result of mechanical energy that is provided by tides, wind stress on the water surface and freshwater runoff (Demers et al. 1986). This energy is then transmitted throughout the water column by turbulent diffusion which is defined by $K_{z}$ the coefficient of vertical diffusion. Uncles \& Joint (1983) note that $K_{z}$ associated with tidal currents is equal to the vertical eddy viscosity, $N_{z}$, which can be calculated as:

$$
N_{z}=K_{0} Z_{\mathrm{m}} u \cdot \eta(1-\eta)
$$

where $K_{0}$ is the Von Karman constant (0.41), $u^{*}$ is friction velocity, $Z_{\mathrm{m}}$ is the depth of mixing, and $\eta$ is the nondimensional depth $(\eta=0$ at the bed and $\eta=1$ at the surface). From this expression one can calculate a timescale $T$ (in hours) for a particle to completely circulate through, for example, the mixed layer

$$
T=a Z_{\mathrm{m}}^{2} / K_{z}
$$

where $a$ is a constant.

This 'circulation time' is of special interest because it gives a measure of how often phytoplankton cells are exposed to near-surface light intensities. For the same value of $K_{z}$ (or $N_{z}$ ) a decrease in $Z_{\mathrm{m}}$ causes a squareroot decrease in $T$. Thus we can calculate that the much-reduced $Z_{\mathrm{m}}$ in Zone 2 would result in a $T$ value 16 times smaller than in Zone 1. Furthermore, Zone 2 is the region of strongest tidal currents (up to almost $1 \mathrm{~m} \mathrm{~s}^{-1}$; Lucotte \& d'Anglejan 1986), it is highly exposed to wind, and is subject to shear effects at the salinity front. All of these effects would further increase the friction velocity $\left(u^{*}\right)$, thus $K_{z 1}$ and even further reduce the timescale of mixing, $T$. Such effects would increase the frequency of exposure of cells to near-surface euphotic light conditions, and probably contributed to the maintenance of the high $P^{\mathrm{B}}{ }_{\max }$ across the TZ. These calculations are consistent with the findings that phytoplankton populations can achieve substantial biomass levels in highly turbid, but shallow and well-mixed estuaries; e.g. Fichez et al. (1992).

\section{Photoadaptation in the upper St. Lawrence Estuary}

Although there is now a large literature on the effects of fluctuating light on algal photosynthesis, there appears to be little consensus between authors. Some studies have shown a significant enhancement of primary production in vertically circulated bottles relative to static incubations (e.g. Marra 1978), while others have shown a significant reduction (e.g. Randall $\&$ Day 1987). The factors causing such differences may include the timescales of photoinhibition and photoadaptation (the photosynthesis-light cascade sensu Vincent 1990) relative to the timescales of mixing and PAR variation experienced by the cells (Cullen \& Lewis 1988). There may also be substantial differences between species in their photoadaptive response to short-term $(<24$ h) light-dark cycles (e.g. MortainBertrand 1989). The present study suggests that the upper extremes of irradiance experienced during growth in a fluctuating light regime may have a strong effect on photoadaptive properties

Our results from the St. Lawrence River system do not support the hypothesis that the phytoplankton were photoadapted to a low mean water column irradiance, but they are consistent with the alternative hypothesis, that the communities were adapted to intermittent exposure to bright, near-surface PAR conditions. The photosynthetic capacity $\left(P_{\text {max }}^{\mathrm{B}}\right)$ was relatively high in Zones 1 and 2, particularly in the second cruise when the water temperatures were much greater. The light limitation parameter $\alpha$ was relatively low, and not indicative of the increased lightharvesting capability that characterises phytoplankton grown under extreme shade conditions. The resultant $I_{k}$ values were at the high end of the range for lakes and oceans (Harris 1978), and imply that the cells were adapted to relatively strong light. Finally, the photoinhibition index $\left(\%\right.$ of $P_{\text {max }}^{8}$ at $1000 \mu \mathrm{mol} \mathrm{m} \mathrm{m}^{-2} \mathrm{~s}^{-1}$ ) was similarly low or negligible in all zones and indicated that the cells were adapted to strong rather than 
dim light conditions. The type of incubation system adopted here is likely to exaggerate photoinhibitory responses (Mallin \& Paerl 1992) yet it failed to demonstrate a major sensitivity to bright light throughout our experiments. These $P$ versus $I$ characteristics may be of special importance for the phytoplankton circulated through the water column of shallow regions of the river and estuary (cf. Cole et al. 1992) and thereby subjected to frequent (but intermittent) exposure to nearsurface photon fluence rates.

In conclusion, the transition from the freshwater reach of the St. Lawrence River to the estuarine turbidity zone was characterized by a marked decrease in underwater light penetration. However, this transition is also accompanied by a decrease in water column depth, with the net effect that there was little change in the ratio $Z_{\text {eu }}$ to $Z_{\mathrm{m}}$ across the frontal region. In both the upstream freshwater environment, and across the saltwater transition, the phytoplankton were adapted towards optimally harvesting the bright light that they were intermittently exposed to at the surface, rather than towards capturing light under the low irradiance conditions experienced on average throughout the water column

Acknowledgements. This research was supported by grants from the Conseil de Recherches en Sciences Naturelles et de Génie du Canada, and from Pêches et Océans, Canada We thank Diane Stewart, Maude Lecourt, Caroline Berger, Michel Boulé and Marie-Hélène Michaud for assistance at various stages in this project; and the master and crew of RV 'Alcide Horth'. We also thank Dr Serge Demers, Institut Maurice Lamontagne, Québec, for his support and advice; Bert Klein, André Cardinal, Jean Painchaud, Nathalie Simard and Ken Lum for helpful discussions; and Professor Julian Dodson for his collaborative input and encouragement throughout all phases of this project.

\section{LITERATURE CITED}

American Public Health Association (1976). Standard methods for the examination of water and wastewater, 14 th edn. American Public Health Association, Washington, DC, p. $424-425$

Bertrand, N., Vincent, W. F. (1994). Structure and dynamics of photosynthetic picoplankton across the salt water transition zone of the St. Lawrence River. Can. J. Fish. Aquat. Sci. 51. 161-171

Cardinal, A., Bérard-Therriault, L. (1976). Le phytoplancton de l'estuaire moyen du Saint-Laurent en amont de l'Ile-AuxCoudres (Québec). Int. Rev. ges. Hydrobiol. 61: 639-648

Cloern, J. E. (1987). Turbidity as a control on phytoplankton biomass and productivity in estuaries. Cont. Shelf Res, 7 : $1367-1381$

Cloern, J. E., Cole, B. E., Wong, R. L. J., Alpine, A. E. (1985). Temporal dynamics of estuary phytoplankton: a case study of San Francisco. Hydrobiologia 129: 153-176

Cole, B. E., Cloern, J. E. (1984). Significance of biomass and light availability on phytoplankton productivity in San Francisco Bay. Mar. Ecol. Prog. Ser. 17: 15-24
Cole, B. E., Cloern, J. E., Alpine, A. E. (1986). Biomass and productivity of three phytoplankton size classes in San Francisco Bay. Estuaries 9: 117-126

Cole, J. J., Caraco, N. F., Peierls, B. L. (1992). Can phytoplankton maintain a positive carbon balance in a turbid, freshwater tidal estuary? Limnol. Oceanogr. 37: 1608-1617

Côté, B., Platt, T. (1983). Day-to-day variations in the springsummer photosynthetic parameters of coastal marine phytoplankton. Limnol. Oceanogr. 28: 320-344

Cullen, J. J., Lewis, M. R. (1988). The kinetics of algal photoadaptation in the context of vertical mixing. J. Plankton Res. 10: 1039-1063

Dauvin, J. J., Dodson, J. J. (1990). Relationship between feeding incidence and vertical and longitudinal distribution of rainbow smelt larvae (Osmerus mordax) in a turbid wellmixed estuary. Mar. Ecol. Prog. Ser. 60: 1-12

Demers, S., Legendre, L., Therriault, J.-C. (1986). Phytoplankton responses to vertical tidal mixing. In: Bowman, J., Yentsch, M., Peterson, W. T. (eds.) Tidal mixing and plankton dynamics. Lecture notes on coastal and estuarine studies, Vol. 17. Springer-Verlag, Berlin, p. 1-40

Dodson, J. J., Dauvin, J. C., Ingram, R. G., d'Anglejan, B. (1989). Abundance of larval rainbow smelt (Osmerus mor$\operatorname{dax}$ ) in relation to the maximum turbidity zone and associated macroplanktonic fauna of the middle St. Lawrence estuary. Estuaries 12: 66-81

Fichez, R., Jickells, T D., Edmunds, H. M. (1992). Algal blooms in high tubidity, a result of the conflicting consequences of turbulence on nutrient cycling in a shallow water estuary. Estuar. coast. Shelf Sci. 35: 577-592

Filardo, J. M., Dunstan, W. M. (1985). Hydrodynamic control of phytoplankton in low salinity waters of the James River Estuary, Virginia, USA. Estuar. coast. Shelf Sci. 21: $653-667$

Grobbelaar, J. U. (1990). Modelling phytoplankton productivity in turbid waters with small euphotic to mixing depth ratios. J. Plankton Res. 12: 923-931

Harding, L. W., Meeson, B. W., Fisher, T. R. (1985). Photosynthesis patterns in Chesapeake Bay phytoplankton: short- and long-term responses of P-I curve parameters to light. Mar. Ecol. Prog. Ser. 26: 99-111

Harding, L. W., Meeson, B. W., Fisher, T. R. (1986). Phytoplankton production in two East Coast estuaries: photosynthesis-light functions and patterns of carbon assimilation in Chesapeake and Delaware Bays. Estuar coast. Shelf Sci. 23: 737-806

Harris, G. P. (1978). Photosynthesis, productivity and growth: the physiological ecology of phytoplankton. Arch. Hydrobiol. Beih. Ergebn. Limnol. 10: 1-171

Joint, J. R., Pomroy, A. J. (1981). Primary production in a turbid estuary. Estuar. coast. Shelf Sci. 13: 303-316

Kranck, K. (1979). Dynamics and distribution of suspended particulate matter in the Saint Lawrence estuary. Nat. can. 106: $163-176$

Laprise, R., Dodson, J. J. (1989). Ontogenetic changes in the longitudinal distribution of two species of larval fish in a turbid, well-mixed estuary. J. Fish. Biol. 35A: 39-47

Livery, S. J., Kaufman, Z., Carpenter, E, J. (1983). Phytoplankton ecology of a barrier island estuary: Great South Bay, New York. Estuar. coast. Shelf Sci. 16: 51-68

Lovejoy, C., Vincent, W. F., Frenette, J.-J., Dodson, J. (1993). Microbial gradients in a turbid estuary: application of a new method for protozoan community analysis. Limnol. Oceanogr. 38: 1295-1303

Lucotte, M., d'Anglejan, B. (1986). Seasonal control of the Saint Lawrence maximum turbidity zone by tidal-flat sedimentation. Estuaries 9: 84-94 
Madariaga, I., Orive, E. (1989). Spatio-temporal variations of size-fractionated primary production in the Gernika Estuary. J. exp. mar. Biol. Ecol. 127: 273-288

Mallin, A., Paerl, H. W. (1992). Effects of variable irradiance on phytoplankton productivity in shallow estuaries Limnol. Oceanogr. 37: 54-62

Marra, J. (1978). Phytoplankton photosynthetic response to vertical movement in a mixed layer. Mar. Biol. 46: 203-206

Mortain-Bertrand, A. (1989). Effects of light fluctuations on the growth and productivity of Antarctic diatoms in culture. Polar Biol. 9: 245-252

Painchaud, J., Lefaive, D., Tremblay, G. H., Therriault, J.-C. (1990). Analysis of the distribution of suspended particulate matter, bacteria, chlorophyll $a$ and $\mathrm{PO}_{4}$ in the upper St. Lawrence Estuary, using a two-dimensional box model. In: Michaelis, W. (ed.) Coastal and estuarine studies Springer-Verlag, Berlin, p. 59-65

Painchaud, J., Therriault, J.-C. (1989). Relationships between bacteria, phytoplankton and particulate organic carbon in the upper St. Lawrence Estuary. Mar. Ecol. Prog. Ser. 56 $301-311$

Pennock, J. R. (1985). Chlorophyll distribution in the Delaware Estuary: regulation by light-limitation. Estuar. coast. Shelf Sci. 21: 711-725

Pennock, J. R., Sharp, J. H. (1986). Phytoplankton production in the Delaware Estuary: temporal and spatial variability. Mar. Ecol. Prog. Ser. 34: 143-155

Platt, T., Gallegos, C. L., Harrison, W. G. (1980). Photoinhibition of photosynthesis in natural assemblages of phytoplankton. J. mar. Res. 38: 687-701

Randall, J. M., Day, J. W. (1987). Effects of river discharge and vertical circulation on aquatic primary production in a

This article was submitted to the editor turbid Louisiana (USA) estuary. Neth. J. Sea Res. 21 $231-242$

Ross, J. C., Pieterse, J. H. (1992). Diurnal variations in the Vaal, a turbid South African river: primary productivity and community metabolism. Arch. Hydrobiol. 124: $459-473$

Strickland, J. S. H., Parsons, T. R. (1972). A practical handbook of seawater analysis. Bull. Fish. Res. Bd Can. 167: $1-130$

Talling, J. F. (1957). Photosynthetic characterization of some freshwater plankton diatoms in relation to underwater radiation. New Phytol. 56: 29-50

Therriault, J.-C., Legendre, L., Demers, S. (1990). Oceanography and ecology of phytoplankton in the Saint-Lawrence estuary. In: El-Sabh, M. I., Silverberg, N. (eds.) Oceanography of a large-scale estuarine system, the St. Lawrence. Springer-Verlag, New York, p. 269-295

Truesdale, V. W., Smith, C. J. (1975). The formulation of molybdosilicic acids from mixed solutions of molybdate and silicate. Analyst 100: 203-212

Uncles, R. J., Joint, I. R. (1983). Vertical mixing and its effects on phytoplankton growth in a turbid estuary. Can. J. Fish. Aquat. Sci. 40 (suppl. 1): 221-228

Vincent, W. F. (1983). Phytoplankton production and winter mixing: contrasting effects in two oligotrophic lakes. J. Ecol. 71. 1-20

Vincent, W. F. (1990). The dynamic coupling between photosynthesis and light in the phytoplankton environment. Verh. int. Verein theor. angew. Limnol. 24: 25-37

Whitledge, T E., Malloy, S. C., Patton, C. J., Wirick, C. D. (1981). Automated nutrient analyses in seawater. Tech. Rep. Brookhaven National Laboratory, Upton, NY

Manuscript first received: December 12, 1993

Revised version accepted: May 2, 1994 